\section{Movimentos de uma performer-pesquisadora amazônida entre risos ameríndios}

\author{
Movements of an amazonian performer-researcher \\ among Amerindian laughs
}

Andréa Bentes Flores ${ }^{1}$

\section{RESUMO}

Neste artigo, cartografo aproximações teóricas e poéticas que atravessam a experiência de meu mapa performativo sobre epistemologias do riso ameríndio na Amazônia. Eu o desenvolvo em três atos de escrita, que perpassam as geografias outras criadas por meu mapa encorporado, a noção de Riso Makunaima e seu caráter grotesco, trapaceiro e obsceno entre comicidades ameríndias, além dos devires da performer em cena, em instabilidade ontológica. Palavras-chave: Mapa. Riso Makunaima. Amazônia. Ameríndios.

\section{ABSTRACT}

In this article, I map theoretical and poetic approximations that cross the experience of my performative map about epistemologies of Amerindian laughter in the Amazon. I develop it in three acts of writing, that involve the other geographies created by my embodied map, the concept of Makunaima Laughter and its grotesque, trickster and obscene characteristic among Amerindian comicalities, and also the becomings of the performer, in ontological instability.

Keywords: Map. Makunaima Laughter. Amazonia. Amerindians.
Professora do Ensino Básico, Técnico e Tecnológico da Escola de Teatro e Dança do Instituto de Ciências da Arte (ICA/UFPA). Doutoranda em Artes pela Universidade Federal de Minas Gerais. ORCID: http://orcid.org/ 0000-0001-9006-7898 Contato:

flores_terapeuta@yahoo.com.br 
Ela está sentada calmamente sobre o palco. As pessoas ali aguardam para ouvir sua fala, na mesa "Saberes da Floresta na pesquisa em Artes da Cena: ensaios teóricos e práticos", durante o Seminário "Epistemologias: transversalidades nas Artes da Cena". Ela divide a cena com Patrícia Pinheiro ${ }^{3}$, Alberto Silva ${ }^{4}$ e Wlad Lima ${ }^{5}$. Falas sobre pesquisas que dialogam com a floresta donde vêm os quatro artistas-pesquisadores amazônidas. Eles trazem a Amazônia inscrita em seus corpos, embora também estejam em aprendizado e pesquisa sobre os saberes que se adensam na mata, enquanto habitam a urbanizada Belém do Pará. O público, recheado de outros pesquisadores, voltava de um breve intervalo no evento. Os rumores de conversa no auditório cessaram logo que viram o que estava sobre o palco. Os quatro, sentados, enfileirados na diagonal, miravam o público. Estado de arte. Wlad iniciou a fala e anunciou a aventura dos outros três, parceiros da cena artística da cidade de Belém. Patrícia segue sua fala. Depois, Alberto. E então chegara sua vez. Pausa.

Cartografo epistemologias do riso ameríndio na Amazônia de floresta profunda. Avanço, floresta adentro, entre escritos de outros que já estiveram no território: antropólogos, poetas, entre outros. Também me preparo para seguir, eu mesma, em viagem, adensando as fronteiras de Amazônia que conheço, habitante que sou de contextos urbanos na região. Faço mapa dos risos que encontro e dos saberes que inspiram em meu corpo, corpo em criação, em pesquisa.

O mapa está no meu corpo. Parto do princípio de que minha criação cênica é pesquisa e que produzo conhecimento encarnado nas ações, utilizando-me aqui do pensamento de Sônia Rangel (2009; 2015), que eu prefiro chamar, para esta experiência, de "pensamento encorporado", com "e", por motivos sobre os quais tratarei mais adiante. Minha escrita tem tom memorial, da artista que compreende, torna visível e comunicável sua poética e o processo de criação, cujo trajeto compreende o próprio desenho do mapa no corpo da performer.

Minhas reflexões, nesta escrita, são mapa sobre mapa. Procuro cartografar tangências e transparências, junto a algumas noções e ideias com quem tenho me encontrado e inventado, na tentativa de seguir meu trajeto de pesquisa em epistemologias do riso ameríndio até aqui. Novamente, aciono termos de Sônia Rangel (2009; 2015), para quem o autor é o único sujeito capaz de expor, de dentro para fora da obra, as escolhas e relatos de seus encontros com autores e artistas que se aproximam de seu modo de pensar o processo criativo em questão, de sua expressão poética. O diálogo com esses parceiros de cena, como gosto de dizer, se dá não
2.

O Seminário "Epistemologias: Transversalidades das Artes da Cena", ocorreu de 03 a 05 de outubro de 2016, em Belo Horizonte, MG, organizado pelo grupo de pesquisa CRIAArtes e Transdisciplinaridade, um laboratório da Escola de Belas Artes da Universidade Federal de Minas Gerais, registrado o CNPq.

3.

Atriz-pesquisadora da cidade de Belém, PA. Professora da Escola de Teatro e Dança da Universidade Federal do Pará (ETDUFPA). Doutoranda em Artes pelo doutorado interinstitucional da Universidade Federal de Minas Gerais (DINTER/UFMG).

4.

Ator, diretor e encenador na cidade de Belém, PA. Professor da ETDUFPA. Doutorando em Artes pelo doutorado interinstitucional da Universidade Federal de Minas Gerais (DINTER/UFMG).

5.

Atriz, diretora e cenógrafa de teatro na cidade de Belém, PA. Professora-pesquisadora da ETDUFPA e do Programa de Pós-Graduação em Artes da mesma universidade (PPGARTES/ICA/UFPA). Doutora e mestre em Artes Cênicas pelo Programa de PósGraduação em Artes Cênicas da Universidade Federal da Bahia (PPGAC/UFBA). Estágio de pós-doutorado em Estudos Culturais junto a Universidade de Aveiro, Portugal. 
pela discussão e explicação, mas por tentativas de compreender a poética em si, a partir das "tangências" e "transparências" inspiradas pelos encontros teóricos e poéticos do caminho de pesquisa-criação.

É o que faço neste artigo, tecido em três atos de escrita. Em cada ato, um corpo feito apenas de momentos de encontro, fluxos. Corpo-sem-órgãos, que Antonin Artaud convoca como saída dos juízos, prisões e automatismos a nos cercear, enunciados acionados por Deleuze e Guattari (1996) para dizer de um exercício, uma prática, ato de desfazer o eu, experimentar a si mesmo, numa vitalidade não orgânica, o abrir-se ao fluxo. A escrita deixa de ser um organismo organizado e passa a se constituir por conexões, agenciamentos, circuitos, desterritorializações (RESENDE, 2009). Em cada ato, intensidades que atravessam meu processo de pesquisa em criação, sem a tentativa de organizar, clivar e enquadrar a vivência em nichos, mas num esforço, num exercício de comunicar os atravessamentos que a poética inspira.

Ao atravessar cada ato, é possível acompanhar por onde se move meu corpo, meu mapa, atendendo ao convite que faço ao leitor para acompanhar-me mata adentro. Mas é também possível testemunhar por onde se liberta o corpo, desorganiza-se, abre-se, deixa de interpretar para experimentar. Não há como entrar na floresta e sair ileso.

\section{Ato 1: Um mapa performativo}

Os parakanã são um povo tupi-guarani encontrado no Estado do Pará, que vivia numa área de floresta a oeste do rio Tocantins. Por volta do final do século XIX, uma briga por mulheres gerou a cisão do grupo em parakanãs ocidentais e parakanãs orientais, que então se tornaram inimigos, com habitações e modos de vida distintos. Em sua etnografia, Carlos Fausto (2014) relata os modos de vida e o processo histórico de formação dos dois grupos. Em dado momento de seus escritos, ele cita que esses sujeitos têm uma maneira peculiar de relacionar-se com o território em que vivem, de maneira que, para o antropólogo, território não seria o melhor nome para corresponder à maneira pela qual os parakanã definem a área por eles habitada.

$\mathrm{Na}$ língua parakanã, essa área é denominada com a palavra "mata" (-ka'a), precedida por um pronome possessivo de primeira pessoa do plural exclusiva, formando o termo "nossa mata" (ore- ka'a). O espaço da habitação é mais do que um pedaço abstrato de terra, sobre o qual um coletivo exerce soberania. Ore-ka'a remete a "[...]uma faixa de floresta conhecida na atividade cotidiana e reco- 
nhecida pela inscrição desses atos, através do tempo, no espaço físico e na memória coletiva" (FAUSTO, 2014, p.105). O etnógrafo sugere o termo "silvitório", cujo prefixo remete diretamente à forte e ancestral relação com a parte da floresta que escolhem para viver. Os silvitórios são permeados por topônimos, nomes que os indígenas atribuem a lugares onde circulam experiências passadas que ficaram marcadas para aquele povo.

Os topônimos, muitas vezes, guardam a marca de uma origem circunstancial: os orientais, por exemplo, denominam o rio Lontra Jara'ira, porque lá teria morrido um homem com esse nome; Apinerenawa é como chamam uma área na bacia do rio da Direita, onde jazia o crânio (apinera) de um inimigo. Os ocidentais, por sua vez, chamaram um pequeno curso d’água na bacia do Pacajá de Jyohoa ("machadão"), porque lá esqueceram certa feita um machado; o Pucuruizinho era conhecido como Inajy'anga, porque lá encontravam uma casa coberta com palha de inajá. Esses nomes são antes qualificações restritivas de deíticos que, pelo uso recorrente, se tornam designações de lugar, isto é, lexicalizam-se como topônimos. Um nome parece resultar, assim, de um longo processo de uso de uma referência locativa, remetendo com frequência a acontecimentos passados (FAUSTO, 2014, P.105).

Uma artista-pesquisadora que transita Amazônia adentro, ensaiando suas primeiras tentativas de entrada na floresta e devagar estabelece relações com outras experiências já vividas naqueles territórios. Não os habita como espaços abstratos de terra, mas como trechos de floresta conhecidos pelos usos, pela inscrição de atos decorrente da experiência ancestral de habitação e produção de saberes. Nossa mata, mata de saberes e risos que compartilho na pesquisa em que cartografo comicidades ameríndias, nessa Amazônia de floresta profunda.

Meu corpo, em descobertas dentro da floresta, compõe um mapa poético, performativo, extraviado, de epistemologias cômicas permeadas pelo xamanismo, por saberes ancestrais, por formas de se relacionar com o território e entre si capazes de gerar novas formas de compreender o mundo. Faço conexões em meu corpo, dobras com outros pensamentos, e devolvo cena, mapa de criação. Em meu corpo crio espécies de topônimos, marcos e pontos relevantes do mapa a partir de minha experiência no espaço, que vão à cena.

Reconheço a possibilidade de operar com um mapa performativo em meu fazer-pensar pesquisa a partir das relações que a artista-pesquisadora Renata Marquez (2009) propõe em sua tese. O mapa performativo estaria próximo do manual de navegação diletante, do desejo, do extravio, da cartografia em existência com o espaço, que age sobre ele, faz viver, cria mundos. 
A experiência está em contraponto ao mapa fixo e desértico, com escalas bem definidas, que remonta à clássica fixidez do olhar vertical, a medir o território de forma segura e imparcial. Aqui não se trata de medir. Em sua análise de artistas que produzem obras entendidas como acionadoras de certos vetores de mutação do espaço e dos seus conceitos, a autora propõe que surge aí outra geografia, coexistente à disciplina científica, capaz de promover a construção da qualidade poética e política da prática cotidiana. Essas obras são denominadas de geografias portáteis, porque fornecem algo movente, compartilhável, que se assemelha a um manual de navegação pelas alteridades do espaço, isto é, tudo o que a objetividade científica negligencia como experiência de conhecimento. Tais geografias provocam a imersão nessas outras ecologias cotidianas e a criação de diferentes espacialidades.

Outros topônimos no território do e para o corpo. Outras formas de pensamento, acompanhadas de outras imagens do corpo. Meu mapa performativo altera as topografias corporais que me constituem. Fernando Mencarelli (2013), escrevendo sobre a experiência transcultural do teatro de Jerzy Grotowski, especialmente na passagem da fase Parateatral para a que ficou conhecida como Teatro das Fontes, menciona que essas topografias são mapas mentais gerados pelos diferentes substratos de cultura. E os diferentes cruzamentos culturais, como pesquisou Grotowski em sua Antropologia teatral, atravessam outras concepções, outras geografias de corpo. O encontro com práticas diversas de cultura geram territórios de aprendizagem e alargamento de percepção. A cartografia que faço alarga-me, altera as geografias de meu corpo e, enquanto ação no espaço, o reconfigura e devolve outras paisagens.

O performativo remete à ideia da valorização da ação em si, para além de seu valor de representação, mimesis. Nessa direção, o fazer é primordial, conforme explica Josette Féral (2015), em sua tentativa de compreender o performativo como marca das práticas artísticas teatrais contemporâneas. $\mathrm{O}$ ator aparece como performer, alguém que coloca o corpo, o jogo e as competências técnicas à frente da preocupação com a construção de sentido, de maneira que, confrontado com esse fazer, o espectador é convidado a encontrar o sentido por si só. O acontecimento se dá no real, com enfoque no momento e no espaço em que se inscreve, sempre abrangendo o risco, a possibilidade de não ser efetivo.

Algo semelhante acontece com os mapas, quando imbuídos de performatividade. Eles são marcados por ambigüidade, des- 
lize de sentido, paradoxos, sobreposição de significados, termos que Féral (2015) aplica ao teatro dessa natureza, mas que, proponho, se aplica aos mapas-obras dos artistas com quem Marquez (2009) estabelece diálogo. Mapas móveis, como o corpo, cuja mobilidade e liberdade desafia a divisão em órgãos, a formação de conhecimentos estáticos, estáveis, revelando sua selvageria, que não cabe nas linhas limítrofes das duras escalas, mas que constrói conhecimento fundamentado em relações subjetivas. Sentido aberto. Mapa que não é fixidez, mas coisa-em-ação no território.

Digo, estabelecendo pontes próprias de minha cartografia, que o que fazem os parakanã, mapeando seu território por topônimos, é criar para si uma geografia portátil, performar o mapa do branco sobre a floresta em que habitam, seu silvitório. Eles agem sobre o território e tomam para si, acionam a memória coletiva, a meu ver, como dispositivo de resistência epistêmica. Eles substituem o saber vertical, instituído, por outros produzidos na experiência cotidiana e de seus antepassados com a mata, renomeando e, assim, reconfigurando o espaço. No mapa parakanã, não há rio Lontra, há Jara'ira. A habitação não é qualquer área, é "nossa mata".

Meu corpo empreende esforço semelhante. Sigo em busca de pistas sobre o riso ameríndio na Amazônia e crio tensões, relações, dobras performativas dos saberes que emanam desse riso. $\mathrm{O}$ que levo à cena e à escrita memorial é um corpo atravessado por outras epistemologias, corpo de Amazônia urbana, que, pela primeira vez, olha para dentro do território onde sempre viveu. Neste mesmo corpo há encontro, experiência, passagem e produção de saberes performados com a floresta, a partir dela, criando fricção e ficção vitais, coexistentes entre os risos da floresta e o convite ao pensamento desacostumado, por assim dizer.

Pensar a geografia portátil é justapor, num mesmo corpo, sujeito e passagem, experiência e conhecimento, espaço e prática espacial. A condição portátil desencadeia a autonomia de ação e a liberdade de criação de novas ficções vitais, praticando uma micropolítica [...] de entendimento e de proposição de formas de coexistência (MARQUEZ, 2009, p.238).

Relembro da geofilosofia deleuziana: "pensar se faz antes na relação entre o território e a terra” (DELEUZE, 1992, p.113). A terra desterritorializa o território e este lhe reterritorializa, em movimento contínuo, cujo início não pode ser demarcado. Eu revisito essa noção como um manifesto, que convoca a experimentar a desterritorialização do corpo-conhecimento, a partir 
da terra, de outras terras, e gerar deslocamentos. É a partir da geofilosofia deleuziana que o antropólogo Eduardo Viveiros de Castro (BARCELLOS; LAMBERT, 2012) convida a viver uma experiência com o pensamento, ao invés de permanecer no próprio pensamento. Não pensar como o indígena, a imitá-lo, em tentativas impossíveis de ser o que não sou; mas pensar com esse pensamento, através dessa epistemologia, numa espécie de experimento do pensar.

Meu mapa é um experimento do pensar e do encorporar. Do pensamento encorporado que se desenvolve com o pensamento indígena na Amazônia. Crio, performo conceitos a partir do riso ameríndio. Essas epistemes contaminam minhas formas de pensar-criar.

Não se trata de dizer "olha só, os índios também têm conceito". Isso
seria ridículo, os índios não pediram para ter conceito, não pediram
essa honra. Seria patético imaginar que a grande aspiração dos
índios fosse virar filósofo; como se fosse a coisa mais importante do
mundo, como se todo mundo quisesse ser filósofo quando crescer.
Mas é perfeitamente possível pensar o pensamento indígena e
tentar fazer conceitos com ele, com base nele, como se pode fazer
conceito com base na arte, na literatura, na experiência de vida, em
certas estéticas da existência (BARCELLOS; LAMBERT, 2012, p.263).

Pensar, fazer conceitos com o pensamento, deixá-los atravessar meu corpo. Seria este um esforço que se conecta à Antropologia Teatral de Grotowski, e outras ações de nomes do teatro moderno e contemporâneo que o antecederam ou seguiram seu trabalho transcultural, ao esforçar-se por ir em busca de novas ressonâncias, outras pulsões, ao reconhecer a alteridade como nossa singularidade, que potencializa a condição humana e se constitui em nova alteridade? Como afirma Mencarelli (2012, p.140), "A prática deslocada não é a prática original, locada. O corpo modificado pelo encontro também não é mais o mesmo corpo do desconhecimento. Há uma ampliação e amplificação da experiência".

Sigo performando minha cena e meus escritos, com o pensamento-corpo que se constrói pelo pensamento ameríndio, no mapa dos risos da Amazônia de floresta profunda. Riso que é conhecimento e que me invade, amplificando-me entre cobras, onças e macacos, entes da floresta a me povoar, em devir, e que convoca epistemes ignoradas pelas linhas delimitatórias de territórios e formas de conhecimento. Isto é o que atravessava aquela mulher, eu, sobre a qual me referi no princípio deste artigo, preparando-se para comunicar uma experiência entre saberes da floresta, acompanhada de seus parceiros de vida e cena. 
Ato 2: Riso Makunaima e os devires da performer-pesquisadora em processo de desocidentação

Sentada naquela cadeira, não se podia confiar na tranquilidade que eu aparentava, prestes a falar no auditório. A plateia observava-me desconfiada. Sentia-me de tocaia, guardando energia para o ataque. Nesse estado, proferi as palavras de Davi Kopenawa (KOPENAWA, ALBERT, 2015, p.103):

As mulheres das águas nunca me levaram para sua casa, nunca me deitaram em suas redes. Preferem os filhos de xamãs. Assim é. Apesar disso, eu nunca deixei de ver os xapiri em sonho, desde que era pequeno, mesmo sem saber quem eram. Foi só muito mais tarde, já adulto, que apresentei meu nariz aos xamãs mais velhos para que me dessem seus espíritos. Senti vontade disso por conta própria. Achei que seria bonito poder ver as coisas de verdade e assim, aos poucos, fui me afeiçoando aos xapiri.

Dias antes, em Belém, no encerramento de uma disciplina do doutorado, compartilhei meus escritos com o mesmo trecho do relato do xamã yanomami, em um desafio de escrita e comunicação performativa para aquela disciplina. Considerei aquele um ensaio para o que viria depois, no seminário. Davi Kopenawa refere-se ao olhar dos xapiri, seres míticos ancestrais daquela cultura, que se interessam por algumas pessoas da comunidade desde crianças para que venham a tornar-se xamãs no futuro. Desde cedo, a criança vê os xapiri em sonho e, mais tarde, decide se seguirá o intento espiritual de ser iniciado na função de xamã ou se prefere não fazê-lo. Davi não é filho de xamã, condição que normalmente guia o interesse dos xapiri. Mesmo assim, como ocorre com alguns, ele recebe o afeto dos espíritos e também se afeiçoa a eles, resolvendo trilhar esse caminho. Escolhi o relato de Davi Kopenawa porque faz ressonância com minha condição atual de pesquisadora, nos interstícios da floresta amazônica.

Não sou filha de xamã. Nunca fui levada pelos povos das águas, que conduzem os xamãs yanomami para o fundo do rio, local da iniciação, processo de tornar-se outro. Algo próximo da ideia de tornar-se malocorpo (CESARINO, 2011), corpo que é maloca, habitada pela imensidão de seres espirituais, a mediar o contato com o mundo físico. Sou palhaça, interessada no riso e nas Amazônias onde habito e sou estrangeira ao mesmo tempo, diante da pluralidade deste território. Já o percorri em busca do riso que eu já conhecia, em pesquisa anterior, procurando por mulheres palhaças atuantes na região, como eu. Estive pelas bordas, pelas capitais. Não consegui entrar, mas avistava o lugar de dentro, da floresta 
adensada. Agora, sinto vontade por conta própria de entregar meu nariz, meu nariz vermelho, aos xamãs ancestrais deste lugar, para que me dêem seu riso.

O riso dos espíritos, malino, grotesco, indecoroso. O riso epistêmico, porque regula e orienta modos de agir e compreender o mundo em comunidade, a impulsionar uma arte do cômico na Amazônia. Entreguei o nariz para encorporação e performatização do riso ameríndio e suas epistemes, meu processo de iniciação.

Naquele dia, em sala de aula, antes do Seminário, performei a entrega de meu nariz. Eu retirei de dentro da roupa o velho nariz vermelho, companheiro de minhas travessuras cômicas como a palhaça Bilazinha, nascida há oito anos no corpo da atriz. Com o nariz nas mãos, levantei-me e entreguei minha preciosa máscara nas mãos de Patrícia Pinheiro, a parceira de doutorado e filha de Tereza de Colares, atriz-xamã amazônica. "Patrícia, por favor, entregue para a madrinha Tereza".

Participo, junto a Tereza de Colares, do ritual do chá sagrado que ela conduz em seu sítio, localizado no município de Colares, $P A$, junto à filha, Patrícia. Tereza é performer e foi iniciada como xamã entre comunidades indígenas da região. Hoje, seu trabalho no sítio agrega um público que cresce sempre, atraídos que somos por modo afetuoso e libertário de viver e conduzir o ritual. Quando me refiro ao chá sagrado, uso um termo que designa a bebida sacramental conhecida na Amazônia por seu uso em rituais xamânicos de várias comunidades indígenas, além de outros rituais que ressignificam a bebida, como o Santo Daime e a Barquinha. Ayahuasca e Daime são alguns dos nomes que o chá recebe, a permear religiões da floresta. Os dirigentes do Santo Daime são chamados de "Padrinho" e "Madrinha", nome carinhoso com que os participantes lhes denominam (ALBUQUERQUE, 2007).

No ritual conduzido por Tereza, a bebida é o chá sagrado. Ela se filia, sem, contudo, seguir rigorosamente os preceitos do Santo Daime. No contexto daquele ato performativo em sala, lembrei dela como madrinha e xamã mais velha com quem tenho contato. Sempre que posso, participo do ritual em Colares com Tereza como quem coloca o corpo em jogo, em ato. A floresta revolve meu corpo com o chá. Risos, bichos e outros aprendizados são apresentados a meus olhos e ouvidos. Todos os sentidos são alterados. E o corpo, em performance, é remexido, desocidentado.

Desocidentar. Desfazer a clivagem entre corpo e espírito. Direcionar-se para fora dos centros capitalistas produtores de conhecimento. Desmanchar os mitos que engrandecem o chamado "homem branco". "Ficar livre da culpa e assumir a potência do super homem", como sugere, enfim, Maria Inês de Almeida, 
em entrevista a Cleber Araújo Cabral e João Rocha (2013, p.179). Com base em sua experiência de criação literária junto a comunidades indígenas amazônicas, ela explica, ainda, que as textualidades que os índios produzem são extra-ocidentais, fora da lógica de racionalidade greco-romana, e são entendidas como processos de cura, de comunicação dos espíritos com os outros. O ato de desocidentar-se tem a ver, assim, com o abrir-se, em escrita e em vida, para a ancestralidade e para a comunidade, em um processo no qual o sujeito rompe com a tradição que o coloca no controle do processo semiótico, e entende que os espíritos transformam-se em letra para a cura da terra e da pessoa.

Desocidentar tem a ver com desorientar, deixar de lado as significâncias desgastadas, em nome do mistério do possível, trocar de posição e de rumo, como sugere Jerusa Pires Ferreira (2009), no prefácio do livro de Maria Inês de Almeida. Reverter, desmanchar, desconstruir, para criar novos impulsos, que têm relação, também, com a preservação do mundo e da natureza por nós esquecidos. Não se trata de criar uma oposição ao Ocidente, tomado como medida e escala única. Isto, Viveiros de Castro (2015) classifica como problemático, já que a dualidade entre Ocidente e Oriente tende a manter a centralidade daquele, como medida hegemônica a que estaria oposto o restante do mundo. O que convoca o termo desocidentado e o verbo dele derivado, desocidentar, "[....]é a replicação infinita de nós mesmos nos outros e deles em nós. A alternância permanente de estar, dizer, respirar" (FERREIRA, 2009, p.14).

O chá sagrado auxilia-me nesse processo de desocidentação de um corpo acostumado às clivagens, dualidades, racionalidades e significâncias desgastadas. Entro na floresta como artista amazônida que conhece o riso clownesco, oriundo de culturas europeias, mas ignora a gargalhada que brota da mata. A sabedoria popular diz que o santo de casa não faz milagres. Neste caso, continuo crendo que o que vem de casa pode até não fazer milagres, mas em se tratando de comicidades da floresta amazônica, penso que sou lançada a intensidades fortes e cômicas, que operam importantes desconstruções e desmanches no corpo. Este é, me parece, um processo de cura, de reconexão com o mistério do possível próprio do território que habito. Desocidentar para replicar-me no riso do outro e no riso deles em mim. Alternâncias em criação, em modos de pensar, em vida.

Ao público presente naquele auditório, comuniquei, então, que já havia entregue o nariz, o nariz vermelho de palhaça, a Tereza de Colares, dias antes. Entregar o nariz significava colocar-me em disponibilidade de alternância com os risos da floresta, jamais extinguir ou posicionar-me contra a arte da palhaçaria que pratico 
por tantos anos. Era, no entanto, urgente ritualizar meu atravessamento por outras comicidades. Riso Makunaima que emana de dentro da floresta.

Meu primeiro encontro com o riso ameríndio se deu por meio da figura mítica de Makunaima, ser presente na cosmogonia dos povos Pemon, termo usado para designar quatro povos indígenas habitantes dos arredores do Monte Roraima. São eles: Macuxi, Taurepang, Arekuna e Kamarakoto. As narrativas desses povos foram publicizadas a partir do trabalho do etnógrafo Theodor Koch-Grünberg, responsável por levar Makunaima para a cultura acadêmica e científica alemã, como conta Fábio Almeida de Carvalho (2009). Makunaima tornou-se Makunaimá e, em seguida, a letra " $\mathrm{K}$ " do alemão foi substituída pelo " $\mathrm{C}$ " do português, na obra de Mário de Andrade. Nasceu Macunaíma, herói de nossa gente (ANDRADE, 2012).

O "herói sem nenhum caráter" foi reidentificado na obra do modernista, cujo projeto de definição de um caráter nacional para a cultura brasileira era a grande motivação (CARVALHO, 2009). Makunaima, o ser mítico das narrativas dos povos Pemon, entretanto, antes de passar pelo olhar do paulista, já fazia suas peripécias entre os mitos por meio dos quais sobrevive na Amazônia e é bem mais antigo que a maneira como grande parte dos brasileiros o reconhece. É a Makunaima e seu comportamento cômico, travesso e criador, que me refiro. Sua maneira de ser e agir no mundo é controversa, grotesca e ele não é o único ser mítico com essa característica, entre os indígenas amazônicos.

Os diversos mitos descritos por Theodor Koch-Grünberg (apud MEDEIROS, 2002) em que Makunaima aparece, oferecem explicação para o surgimento de várias coisas no mundo, desde a criação de animais como a arraia e a cobra, até a forma do tronco das árvores e a aparência de alguns seios ditos feios. Conta um dos mitos que Makunaima desejava deitar-se com uma moça, que, no entanto, não permitia que isso acontecesse e bateu nele. Ela era apaixonada por Kumaye-kima-moínele, o "jovem da árvore Samaúma" e não adiantava querer tirá-la dele, já que ela o achava muito bonito. Makunaima, aborrecido, convoca seus irmãos Jigué e Ma'napé para destruir o opositor. A ideia era amarrar o jovem para que nunca mais ficasse bonito. Eles assim o fizeram, amarrando os braços e pernas de Kumayekima-moínele. Por isso é que, segundo o mito, a Samaumeira não engrossa na parte de baixo do tronco, só na "barriga". É dito que é uma barriguda (t-éwan-yen). Naquele tempo, as mulheres não tinham seios e, não satisfeitos, Makunaima e seus irmãos amarraram em cada lado do peito da moça a ponta extrema do 
caule de cada cacho de bananeira, dando forma cônica a alguns seios femininos.

Travesso, libidinoso, malvado. Grotesco, cômico. Por vezes, bobo. Makunaima cria e destrói, transforma-se noutras coisas, funda e desorienta o mundo, no pensamento mítico dos Pemon. Carvalho (2009, s/p) reflete sobre o contraponto entre o comportamento de Makunaima e o pensamento do branco, exemplificado nos leitores alemães que entraram em contato com o registro de suas lendas:

\begin{abstract}
A leitura dos feitos do herói migrante causou espanto à imaginação dos leitores da Alemanha que, ao se depararem com um ser tão estranho, insolente, cheio de artimanhas e apresentando uma total falta de ética, em sua acepção ocidental, devem ter-se dado conta do quão diferente era aquele herói, que podia se transformar e transformar os demais seres vivos em qualquer coisa que quisesse, ao sabor dos seus cambiantes e ilógicos desejos.
\end{abstract}

A estranheza e insolência de Makunaima se contrapõe à moral dos comportamentos aceitáveis e da imagem de muitas divindades ocidentais. Trickster amazônico, como o denomina Lúcia Sá (2002), figura que se relaciona a um espírito livre, avesso a regras, atravessador de fronteiras, ligado à trapaça e ao engano, que revela facetas da personalidade humana e da ideia de divindade, de fundamental importância em muitos rituais e cosmogonias de povos tradicionais. Volto minha atenção a Makunaima não somente por seu modo de ser, como também pela maneira como sua ressignificação tornou-se conhecida no país e ganhou visibilidade através da obra de Mário de Andrade. Preciso, entretanto, chamar atenção para o fato de que Makunaima e Macunaíma são seres diferentes, esforço já empreendido por outros pesquisadores como Carvalho (2009) e Faria (2006). Convoco o Makunaima amazônico como estratégia política territorializada e passo a utilizar o termo "riso makunaima" para abarcar outras pistas de contornos semelhantes para a comicidade Amazônia adentro, na cosmogonia de outros povos indígenas locais. Há vários outros semelhantes a Makunaima por estas matas, permeando os modos de pensar da floresta.

A antropóloga Joanna Overing (2000) acredita na existência de uma epistemologia da tolice, da bobagem, do cômico, entre os indígenas da Amazônia. O riso seria um componente vital para as comunidades ameríndias, povos que amam o humor obsceno, a brincadeira, que compartilham atitudes semelhantes das divindades e figuras míticas. Sua cotidianidade e forma de compreensão das coisas estão orientadas por esse modo de pensar o mundo e a origem das coisas, permeados pela comicidade. 
Els Lagrou (2009) dialoga com os escritos de Overing e atravessa vários outros exemplos de seres míticos amazônicos, entre outras etnias, que parecem fazer parte dessa epistemologia do riso da floresta, e apresenta exemplos situados entre o sagrado e o cômico, presentes nos relatos sobre povos etnografados por outros antropólogos, além dos Kaxinawa, do Acre, junto a quem desenvolve seu trabalho. O grotesco é imagem comumente associada tanto ao divino, quanto ao humano, de maneira que aspectos risíveis, segundo a autora, são marcadores de tempos de criação, mudanças, conquistas e destruições.

Ñañe, deus dos Airo Pai, na Amazônia peruana, andava pela Terra enganando os seres a quem encontrava, transformando-lhes em animais. Embora seja o criador supremo, hoje está sempre à procura de benefícios próprios e comporta-se como trickster, mudando de aparência para enganar quem lhe procura, sendo aliado somente dos xamãs. Wahari, das narrativas Piaroa, tem um pênis comprido, que ele enrola no pescoço. As mulheres o visitavam na brincadeira de balançar-se até o outro lado do rio, até que o enorme pênis as encontrava e fazia amor com elas durante várias horas. $\mathrm{O}$ marido ciumento das esposas descobre e corta o membro do irmão rival. Por meio dessa narrativa engraçada, é explicada também a origem da menstruação entre aqueles indígenas. Entre os Kaxinawa, Els Lagrou conta sobre Inka, deus mítico todo-poderoso e canibal, que devora a própria perna depois de devorar todas as mulheres que os Kaxinawa lhes oferecem. O que garante o riso da plateia na narrativa desse mito, segundo a antropóloga, é a narração permeada de muita mímica (LAGROU, 2009).

De fato, Overing (2000) destaca que a atitude do narrador de mitos, geralmente um xamã, é bastante cênica, com traços de obscenidade e paródia e cheias de ironia. As palavras são sempre fortes, interessantes, engraçadas. Muito além de contos solenes e maravilhosos sobre onipotência e onisciência divina, o que a antropóloga via eram performances que criavam deleite público, muitas gargalhadas e um entendimento prazeroso do absurdo da condição humana, a partir do indecoroso comportamento dos deuses criadores.

Lagrou (2009, 2007) apresenta, ainda, exemplos da comicidade inserida em sociabilidades cotidianas e contextos rituais do Kaxinawa. Para citar alguns outros exemplos de relatos com este teor, em Barcelos Neto (2008) descubro que uma série de brincadeiras fazem parte do ritual de trazer Apapaatai, entre os Wauja, do Xingu. O ritual de máscaras, destinado a curar doenças provocadas pelo roubo de alma praticado pelos seres Apapaatai, é, também, permeado por gracejos libidinosos entre homens e 
mulheres, que envolvem canções cujo tema principal são ambas as genitálias. Coelho (2014), em sua dissertação sobre a cosmogonia Tembé, do Alto Rio Guamá, no Pará, cita que, durante a Festa da Moça, rito de passagem da infância para a vida adulta, principalmente das meninas, mas também dos meninos, há o momento de verificar se as iniciadas já têm seriedade. Um macaco guariba moqueado é enfeitado com adereços como saia e colares e constantemente usado por seu condutor, no último dia de festa, para provocar o riso das meninas. Seu papel é testar a seriedade, fazendo graça, "macacada", como lhe descreve um dos informantes. Todos riem, mas elas não. Manter a seriedade significa estarem prontas para os desafios da fase adulta.

Cada contexto de relato sobre o riso da floresta merece um olhar específico. Riso das sociabilidades, dos rituais, das narrativas míticas. Eu os convoco aqui como expressões do riso Makunaimá, riso da Amazônia de floresta profunda: grotesco, traquino, obsceno. Comicidade presente na atitude das figuras divinas, como Makunaima, que chega à comunidade pelo corpo do narrador de mitos, mas também no cotidiano dos indígenas e seus rituais.

A performatividade das narrativas míticas ameríndias na Amazônia é um dispositivo do riso Makunaima, acionado pelos xamãs e disseminado no cotidiano das comunidades. Jerome Rothemberg (2006) e seus escritos etnopoéticos ajudam-me a pensar que a narrativa dos povos tradicionais é uma unidade com os seus modos de enunciação. Trata-se de uma experiência poética que engloba os movimentos do corpo, o modo como a voz é usada, o local onde acontece, etc. O poema é composto por todos os acontecimentos envoltos no ato da narrativa, aproximando-se da performance. Compreendo, assim, o riso Makunaima como indissociável da performance etnopoética que o torna existente, nos corpos dos sujeitos ameríndios e seus entes espirituais.

Antes de qualquer coisa, sou um poeta \& (vivendo na época em que vivo) um poderoso performer da minha própria poesia. Para mim é melhor fazer poesia que falar sobre ela. [...] A poesia se torna o som- não o manuscrito em separado, a preparação ou notação, mas o soar. Onde não há nenhuma escrita, o soar de fato renova o poeta, o cria a cada instante, pois aqui não há poema sem performance (ROTHENBERG, 2006, p.92).

Neste momento, a plateia daquele auditório, ouvindo-me falar, assusta-se ao notar que tiro a blusa sobre o palco. É possível ver o maiô transparente que tinha o tempo todo por debaixo da roupa, todo grafado com o que parece uma escrita, mas de grafia ininteligível. Sinto meus olhos abrirem-se em vida, entre fascínio 
e ameaça. Meu sorriso é medonho. Em seguida, corpo tímido e contido, olhar hesitante. E, sem anunciar que o farei, começo a narrar:

Um dia, meu irmão Wahari e eu demos uma festa em nossa casa. Muitos estrangeiros vieram, casa decorada com muito gosto, pintada e perfumada. Todas as partes do nosso corpo estavam perfumadas (risinhos). Wahari ficou preocupado com minha honra e me ordenou que tivesse cuidado com a bebida. Eu gostei muito dos visitantes e bebi com eles. O perfume deles era tão bom! Mesmo assim, obedeci a meu irmão e permaneci casta. Enquanto isso, ele se pôs a beber tudo o que pôde com as mulheres visitantes, e passou um tempo delicioso com os convidados, lá no fundo da casa, onde há riso e onde encontros amorosos acontecem. Uma raiva imensa tomou conta de mim por causa da hipocrisia do meu irmão nessa noite,e passei a me recusar a falar com ele. Não saía da minha cabeça o modo como os homens falavam tão bem comigo. Eles diziam: "Vamos!", e eu havia sido estúpida o suficiente para recusar. Deitei na minha rede e me balançava pra lá e pra cá, cantando sobre o meu desejo pelos homens e sobre o quanto queria "fazer macacada". Wahari, meu irmão, ficou furioso com isso e zombou de mim: "Por que você não foi com esses homens?”. Na raiva dele, lançou a mim e a meus poderes de feitiçaria para a Montanha da Magia. E foi então que sem saber ele me deu exatamente o que eu precisava...

Levanto da cadeira e agora retiro a saia. Meu corpo se retorce, pernas arqueadas, quadril encaixado, a genitália projetada para frente. Braços abertos em arco ao lado do corpo. Percorro o palco:

Onde eu caí, criei o macaco Guariba, que ganhou a forma de animal que tem hoje. Eu me tornei a "Mãe do macaco" e passei a me dedicar a fazer perfumes, que na verdade se tornaram a própria urina do macaco, que eu fiz para eles. Assim eu criei o mal da 'Loucura da Urina do Macaco', o mal da promiscuidade sexual. Os macacos loucos usam sua própria urina como uma poção do amor...

Salto, descendo do palco para os espaços entre as cadeiras e perambulo entre as pessoas:

Eu levo uma vida errante. Visito um grupo de estrangeiros após o outro, criando meus perfumes para eles, fazendo amor e criando mais macacos. Eu espalhei meu perfume pelo mundo. Qualquer um pode ficar louco se usar, e então sofrerá da Loucura da Urina do Macaco, fazendo amor com seus amigos, com os estrangeiros, irmãos ou irmãs.

$E$ é assim que os Piaroa da Amazônia venezuelana explicam o comportamento de promiscuidade sexual de alguns indivíduos (gargalhadas).

Volto para o palco ao som dos risos e olhares descrentes do que viram da plateia, que aplaude. A narrativa, adaptada de um mito Piaroa relatado por Overing (2000), atravessa o corpo da pesquisa- 
dora que é performer de sua própria poesia, de sua poética. Escolho comunicar minha pesquisa dessa forma porque todo meu movimento de rastreio cartográfico do riso ameríndio na Amazônia de floresta profunda destina-se à criação cênica. O corpo inspira-se na performance do narrador de mitos indígena e na performatividade da pesquisa que ali é comunicada. Pesquisa poética, criação.

A cena fora ensaiada dias antes, na sala de aula da mesma disciplina em que entreguei meu nariz vermelho a Tereza de Colares. Ao narrar o mito naquele ensaio, antes da cena no seminário, meu enfoque esteve sobre o corpo sexualmente marcante de Sheheru, a irmã de Wahari, que assumo como primeira pessoa na adaptação que fiz da narrativa. Pernas abertas, olhar faminto, corpo sedutor. Corpo sedutor de quem vive em uma cidade urbanizada. Havia algo de errado. A primeira imagem de Sheheru que compus era marcada por um certo erotismo ocidental, conforme fui alertada em sala, quando discutimos a performance, ao final. No auditório, porém, a mulher que a plateia viu trabalhou noutra direção: a macacada. Corpo simiesco, que adquire sua forma instável progressivamente, sem, contudo, imitar o macaco. Nem o macaco, nem a mulher. Algo entre, devir.

Devir-macaco da performer, não a semelhança: "um devir-animal que não se contenta em passar pela semelhança, para o qual a semelhança, ao contrário, seria um obstáculo ou uma parada" (DELEUZE; GUATTARI, 1997, p.9). Também não se trata de correspondência, nem imitação ou identificação. Como o devir deleuziano, o que passo com Sheheru tem a ver com pulsação e desejo pelo outro. Mais do que parecer com o macaco, passo pelo devir. Não abandono o estado anterior para alcançar algo definido, animal real, mas pulso no bloco em que coexistem a performer cômica, o devir, e esse(s) outro(s) que o riso ameríndio me anuncia.

São muitos os outros pulsantes no corpo da pesquisadora. Mais do que um animal, meu devir em cena é um ente dúbio de dentro da floresta, que aciono com a narrativa mítica. Em meu corpo, ressonâncias do perspectivismo ameríndio de Viveiros de Castro (2011, p.894): "A humanidade de fundo é menos um predicado de todos os seres que uma incerteza constitutiva sobre os predicados de qualquer ser". Cada ser na Amazônia possui uma perspectiva humana própria, tal qual nós em relação aos outros seres. A onça vê os homens como porcos-do-mato e o sangue de suas vítimas como cauim ${ }^{6}$. Toda coisa é humana, explica Viveiros de Castro (2011, 2015), ou ao menos pode se revelar como tal. É preciso desconfiar do que se vê, porque não se pode estar plenamente certo de que o outro, tal como o vemos, assim o seja de fato. Ou melhor, é sempre possível que o animal, o artefato ou a pessoa que vemos
6.

Bebida alcoólica tradicional em comunidades indígenas ameríndias, preparada com mandioca ou milho fermentados. 
revele-se como sendo outra coisa, de maneira que existe sempre a possibilidade de haver um outro do outro, que não cessa de se transformar. E esse outro se compreende como humano.

Para o pensamento ameríndio, diz Viveiros de Castro (2011, 2015), ao revelar-se como algo distinto do que a capacidade visual do observador consegue perceber, o outro, sempre dúbio, também possui uma perspectiva humana própria, que reivindica como soberana. O ente vê a si mesmo e aos da mesma espécie como humanos e aos outros como uma variedade de seres possíveis, sobre a qual não se pode determinar com exatidão.

O corpo simiesco da performer-pesquisadora em cena está em estado de instabilidade ontológica, termo empregado por Barcelos Neto (2008). Devir-outro, o outro impreciso do ato de macacar, que pode revelar a qualquer momento outra forma de existência. São muitas as possibilidades de existência dentro da floresta e velozes os processos de transformação. Eu procuro por esses devires e, por intermédio deles, encorporo o riso Makunaima como epistemologia.

Ato final: Encorporação epistêmica- um guia para outras navegações

Cartografar o riso da floresta entre comunidades indígenas amazônicas implica assumir o estado de meu corpo em criação, em performance, aprendendo a assumir outras perspectivas e encorporá-las. $O$ ato de incorporação torna-se, aqui, encorporação. Uso o termo como uma melhor tradução do conceito antropológico de embodiment, como faz Els Lagrou (2007), ao concordar com a sugestão de Viveiros de Castro (1996; 2015). Para o autor, no pensamento ameríndio não cabem as traduções "encarnar" ou "incorporar", já que a noção de cultura, aqui, consiste na compreensão de esquemas de percepção e ação anteriores à natureza, agora dispostos em uma corporalidade específica. Cultura: única, perspectiva humana em multiplicidade para cada ente, ancestral, existente no tempo mítico. Naturezas: distintas, forma de bicho, planta, artefato, adquiridas depois.

Eu encorporo o outro numa operação epistemológica xamânica, que atua como antípoda da epistemologia objetivista da modernidade ocidental, tal qual explica Viveiros de Castro (2015, p.50). Para esta última, conhecer é objetivar, dessubjetivar, extinguindo do objeto o que diz respeito que sujeito que conhece, em nome do que lhe é próprio, para que perca seu caráter irreal e abstrato. No xamanismo, entretanto, que o antropólogo reconhece como modo de agir e modo de conhecer, ou um ideal de conhecimento, a operação é contrária. O outro não é objetivado. Conhecer implica em 
personificar, "tomar o ponto de vista daquilo que deve ser conhecido. Ou antes, daquele; pois a questão é a de saber "o quem das coisas" (Guimarães Rosa), saber indispensável para responder com inteligência à questão do "por quê".

Esse ato de encorporação do outro é gerado, na performer-pesquisadora, pelo desejo da alteridade que alimento conforme adentro a floresta. Experimento outras possibilidades e perspectivas de ser, seguindo floresta adentro como quem precisa alimentar-se, como quem deseja alterar as linhas de composição do próprio corpo, desocidentar entre epistemologias do riso ameríndio. Empresto a proposição de Joana Overing e a reelaboro para o contexto desta pesquisa. O riso Makunaima cumpre um papel importante na compreensão de mundo dos ameríndios e, como performer, eu sigo suas pistas deixando-me alterar pelas epistemologias que emanam da floresta em minha busca.

O pensar como experimentação, a partir da floresta, em performance, em ato, coisa-em-ação, que chega ao olhar do outro. E o que acontece com este mapa, para além de meu corpo?

o que ocorre quando o mapa se transforma em coisa-em-ação, para
além da sua função instrumental de ser legível? Aí, a sua proprie-
dade comunicacional desdobra-se de leitura cartográfica para uma
densidade perceptiva ou uma prática espacial. Como manifesto
particular, o mapa pode ser reinstrumentalizado como manual,
dispositivo do relato novo, guia para navegaçães cotidianas que vão
além do seu lugar-matriz. Extravios cartográficos são propostos
por cartógrafos conscientes do poder de discurso e críticos quanto
à autoridade nada inocente da formação de um pensamento de
mundo inerente a todo mapa. (MARQUEZ, 2009, p.84).

A floresta extravasa. O território se desdobra em outras possibilidades, cuja criação não cessa de acontecer. Disponível ao outro, que lhe atribui sentido, torna-se um guia para outras navegações, para além de seu lugar-matriz. Não um manual, mas um dispositivo para outros deslocamentos. Não há inocência, busco criticidade na encorporação do riso ameríndio, deslocamento, viradas epistêmicas, que ressoam a partir das dilatações de mim e dos espaços onde transito, em outros artistas-pesquisadores. Sheheru em cena convida todos a macacar, enquanto vivo meus próprios devires. Duplo devir, desterritorialização e reterritorialização (DELEUZE, 1992). Em direção ao ameríndio, para que as epistemes surgidas nesse encontro façam conexões com outros corpos.

Quando Davi Kopenawa (KOPENAWA; ALBERTI, 2015, p.136) fala em entregar seu nariz aos xamãs mais velhos, percebo que passa por um violento movimento de desterritorialização, próprio do processo de iniciação xamânica. O mais experiente, no caso de 
Davi o que ele chama de um grande xamã ancião, assopra enormes quantidades de pó de yãkoana, tirado da seiva de árvores, no nariz do iniciado. O pó, considerado alimento dos xapiri, tem poder forte e duradouro, deixando o corpo de Davi prostrado e dolorido. É o pó "que faz com que as palavras dos espíritos se revelem e se propaguem ao longe". Os espíritos levam a imagem do iniciado para longe, em voos distantes e fazem ver coisas desconhecidas. Com o tempo, o xamã já iniciado já não cai no chão e consegue manter-se em pé para cantar e dançar, a fim de revelar as coisas à comunidade, curar e trazer ensinamentos.

Nariz entregue, tempo de sentir dolorir o corpo, de deixar-me levar em voos distantes, de ver coisas desconhecidas. Tempo de prostrar, de cair da verticalidade do pensamento, e experimentar a sabedoria dos espíritos da floresta. Espíritos risíveis, grotescos. Tempo de desocidentar, desorientar, performar o mapa desses voos e compor outras geografias, habituar-se devagar a essas viagens e devolver ao outro pistas de cura, conhecimento encorporado.

Nos meus atos de escrita, um convite para sair do estado de testemunha de meus movimentos e embarcar nas transformações por que passa meu corpo, ao atravessar os saberes inventados, performados no mapa. Epistemologias que convidam o leitor a criar para si um corpo sem órgãos, a desocidentar e a propor atravessamentos. Chegue mais perto. Não tão perto. Tenho cheiro de onça, corpo de macaco e rastejo como cobra. O devir é intenso e o desejo de devorar é quase incontrolável. 


\section{REFERENNCIAS}

AlbuQUerque, Maria Betânia Barbosa. ABC do Santo Daime. Belém: EDUEPA, 2007. 96p. ISBN 978-85-88375-18-5

ANDRADE, Mário de. Macunaíma, o herói sem nenhum caráter. Rio de Janeiro: Nova Fronteira, 2012.

BARCELLOS, Larisse; LAMBERT, Cleber. Entrevista com Eduardo Viveiros de Castro. Revista Primeiros Estudos, São Paulo, n. 2, p. 251267, mai. 2012. Disponível em: < http://www.revistas.usp.br/primeirosestudos/article/view/45954>. Acesso em: 20 mar. 2017.

BARCELOS NETO, Aristóteles. Apapaatai: rituais de máscaras no Alto Xingu. São Paulo: Edusp/ Fapesp, 2008. 336p. ISBN 978-85-314-1066-6 CABRAL, Cleber Araújo; ROCHA, João. Desocidentar-se: aberturas e caminhos para o outro, entrevista com Maria Inês de Almeida. Em Tese, Rio de Janeiro, v.19, n.3, p.178-180, set./dez. 2013. Disponível em: < http://www.periodicos.letras.ufmg.br/index.php/emtese/ article/viewFile/5500/4913>. Acesso em: 20 mar. 2017.

CARVALHO, Fábio Almeida de. Malkunaima/Malunaíma, antes de Macunaíma. Revista Crioula, São Paulo, n.5, s/p., mai. 2009. Disponível em:<http://www.revistas.usp.br/crioula/article/view/54943>.Acesso em: 18 mar. 2017.

CESARINO, Pedro de Niemeyer. Oniska: poética do xamanismo na Amazônia. São Paulo: Perspectiva: Fapesp, 2011. 423p. ISBN 978-85-273-0906-6

COELHO. José Rondinelle Lima. Cosmologia Tenetehara Tembé: (re)pensando narrativas, ritos e alteridade no Alto Rio Guamá PA. 2014. Dissertação (Mestrado em Antropologia Social) - Museu Amazônico, Universidade Federal do Amazonas, Manaus, 2014. DELEUZE, Gilles. O que é a filosofia?. Rio de Janeiro: Ed. 34, 1992. 279p. ISBN 85-85490-02-0 DELEUZE, Giles; GUATTARI, Félix. 28 de novembro de 1947- Como criar para si um corpo sem órgãos. In: DELEUZE, Giles; GUATTARI, Félix. Mil Platôs: capitalismo e esquizofrenia, vol.3. São Paulo: Ed. 54, 1996. p.9-29. 107p. ISBN 85-7326-017-3

DELEUZE, Giles; GUATTARI, Félix. Devir-intenso, devir-animal, devir-imperceptível. In: DELEUZE, Giles; GUATTARI, Félix. Mil Platôs: capitalismo e esquizofrenia, vol.4. São Paulo: Ed. 54, 1997. p.8-99. 176p. ISBN 85-7326-050-5

FARIA, Daniel. Makunaima e Macunaíma: entre a natureza e a história. Revista Brasileira de História. São Paulo, v. 26, n. 51, p. 263280, jan./jun. 2006. Disponível em: <http://www.scielo.br/scielo. php?pid=S0102-01882006000100013\&script=sci_arttext $>$. Acesso em: 18 mar. 2017.

FAUSTO, Carlos. Inimigos fiéis: história, guerra e xamanismo na 
Amazônia. São Paulo: Edusp, 2014. 592p. ISBN 978-85-314-0574-7 FÉRAL, Josette. Por uma poética da performatividade: o teatro performativo. In: Além dos limites: teoria e prática do teatro. São Paulo: Perspectiva, 2015. p.113-131. 424p. ISBN 973-85-2731027-7 FERREIRA, Jerusa Pires. Prefácio: desocidentar/desorientar. In: ALMEIDA, Maria Inês de. Desocidentada: experiência literária em terra indígena. Belo Horizonte: Editora UFMG, 2009. p.13-15. 147p. ISBN 978-85-7041-756-5

KOPENAWA, Davi; ALBERT, Bruce. A queda do céu: palavras de um xamã yanomami. São Paulo: Cia. Das Letras, 2015. 729p. ISBN 978-85-359-2620-0

LAGROU, Els. A fluidez da forma: arte, alteridade e agência em uma sociedade amazônica (Kaxinawa, Acre). Rio de Janeiro: Topbooks, 2007. 565p. ISBN 85-7475-130-8

LAGROU, Els. $\mathbf{O}$ riso grotesco e o riso festivo: narrativas e performances kaxinawa. In: CAVALCANTI, Maria Laura Viveiros de Castro; GONÇALVES, José Reginaldo Santos. (Orgs.). As festas e os dias: ritos e sociabilidades festivas. Rio de Janeiro: Contra Capa, 2009. p.169-196. 272p. ISBN 978-85-7740-012-6

MARQUEZ, Renata Moreira. Geografias portáteis: arte e conhecimento espacial. 2009. Tese (doutorado em Geografia) - Instituto de Geociências, Universidade Federal de Minas Gerais, Belo Horizonte, 2009.

MEDEIROS, Sérgio(Org.). Makunaímae Jurupari:cosmogoniasameríndias. São Paulo: Perspectiva, 2002. 413p. ISBN: 85-2733-0301-9 MENCARELLI, Fernando Antonio. Mapas e Caminhos: práticas corpóreas e transculturalidade. Revista Brasileira de Estudos da Presença, Porto Alegre, v. 3, n. 1, p. 132-143, jan./abr. 2013. Disponível em: <http://www.seer.ufrgs.br/presenca>. Acesso em: 20 mar. 2017. OVERING, Joanna. The efficacy of laughter: the ludic side of magic within amazonian sociality. In: OVERING, Joanna; PASSES, Alan (Orgs.). The anthropology of love and anger: the aesthetics of conviviality in native Amazonia. Londres: Routledge, 2000. p. 64-81. 305p. ISBN 978-0-415-22418-5

RANGEL, Sonia. O olho desarmado. Salvador: Solisluna, 2009. 132p. ISBN: 978-85-89059-17-6

RANGEL, Sonia. Trajeto criativo. Lauro de Freitas: Solisluna, 2015. 79p. ISBN: 978-85-89059-70-1

RESENDE, Catarina. A escrita de um corpo sem órgãos. Fractal Revista de Psicologia, Niterói, v.20, n.1, p.65-76, jan./jun. 2008. Disponível em: < http://www.uff.br/periodicoshumanas/index. php/Fractal/article/view/26>. Acesso em: 20 mar. 2017.

ROTHENBERG, Jerome. Etnopoesia no milênio. Rio de Janeiro: Azougue Editorial, 2006. 254p. ISBN 85-88338-51-3 
SÁ, Lúcia. Triclksters e mentirosos que abalaram a literatura nacional: as narrativas de Akúli e Mayuluaípu. In: MEDEIROS, Sérgio (Org.). Makunaíma e Jurupari: cosmogonias ameríndias. São Paulo: Perspectiva, 2002. p.245-259. 413p. ISBN: 85-2733-0301-9 VIVEIROS DE CASTRO, Eduardo. Metafísicas canibais: elementos para uma antropologia pós-estrutural. São Paulo: Cosac Naify, 2015. 288p. ISBN 978-85-405-0930-6

VIVEIROS DE CASTRO, Eduardo. Os pronomes cosmológicos e o perspectivismo ameríndio. Mana, Rio de Janeiro, v.2, n.2, p.115-144, out. 1996. Disponível em: <http://www.scielo.br/scielo.php?script=sci_ arttext\&pid=S0104=93131996000200005-\&lng=pt\&nrm=iso\&tlngpt>. Acesso em: 10 mar. 2017.

VIVEIROS DE CASTRO, Eduardo. O medo dos outros. Revista de Antropologia. São Paulo, v. 54, n. 2, p.885-917, 2011. Disponível em: < http://www.revistas.usp.br/ra/article/view/39650>. Acesso em: 10 mar. 2017. 